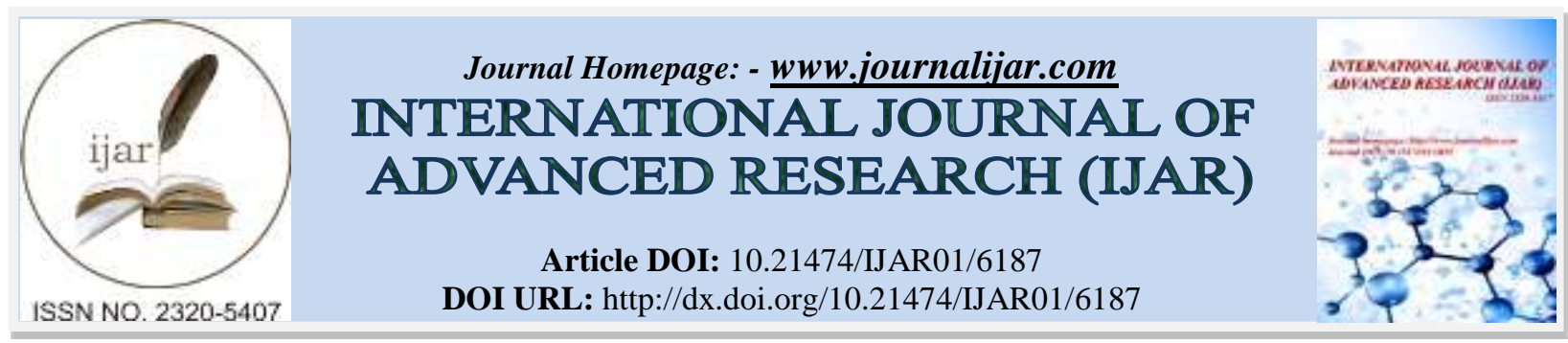

RESEARCH ARTICLE

\title{
REMOVAL OF RADICAL CYST IN PREVIOUS REGION OF MAXILA: CASE REPORT AND INTEGRATIVE REVIEW.
}

Severino Alexandre Barbosa da Silva ${ }^{1}$, Jefferson David Melo de Matos ${ }^{1}$, Jaqueline Alves do Nascimento ${ }^{1}$, Sérgio Éberson da Silva Maia ${ }^{1}$, Rafaela Vasconcelos de Melo Lima ${ }^{2}$, Ricardo Barreto Almeida Vasconcelos ${ }^{2}$, Amanda de Lavor Bezerra ${ }^{3}$, Antonio Jackson Andrade Gonzaga de Oliveira ${ }^{4}$, Bruna Caroline Gonçalves de Vasconcelos ${ }^{5}$, Lucas Villaça Zogheib ${ }^{6}$, Jozely Francisca Mello Lima ${ }^{7}$, Daniel Sartorelli Marques de Castro ${ }^{8}$, Tiago Norões Gomes ${ }^{9}$, John Eversong Lucena de Vasconcelos ${ }^{9}$ and Victor Archeti Vardiero ${ }^{9}$

1. School of Dentistry, Centro Universitário UNILEÃO, Juazeiro do Norte - CE, Brazil.

2. School of Dentistry, Faculdade Mauricio de Nassau, Recife - PE, Brazil.

3. Master's Degree in Endodontics, San Leopoldo Mandic, Campinas - SP, Brazil.

4. Graduate in Letters - English Language, Universidade Regional do Cariri - URCA, Crato - CE, Brazil.

5. Master's Degree of Orthodontics, San Leopoldo Mandic, Campinas - SP, Brazil.

6. Professor of Dental Prosthetics, Department of Dentistry, Universidade de Fortaleza UNIFOR, Fortaleza - CE, Brazil.

7. Professor of Dental Prosthetics, Department of Dentistry, Faculdade Paulo Picanço, Fortaleza - CE, Brazil.

8. Professor of Dental Prosthetics, Department of Dentistry, Centro Universitário Christus - UNICHRISTUS, Fortaleza-CE, Brazil.

9. Professor of Oral Implantology, Department of Dentistry, Centro Caririense de Pós-Graduação CECAP, Juazeiro do Norte - CE, Brazil.

\section{Manuscript Info}

\section{Manuscript History}

Received: 02 November 2017

Final Accepted: 04 December 2017

Published: January 2018

Key words:-

Radicular Cyst, Pathology Oral, Odontogenic Cysts, Surgery Oral.

\section{Abstract}

Aim: The objective of the present study is to report a clinical case of a successful treatment, related to the removal of a radicular cyst in the anterior region of the maxilla. Methodology: A bibliographic search was carried out in the main databases: PUBMED, ScIELO, Google Scholar, VHL and LILACS, which collected works that were published from 2002 to 2017 . We collected 33 articles, which were extracted from the databases as previously reported; It was included laboratory studies, case reports and systematic reviews as well as literature that were developed in the human species. Results: Based on the review, all studies showed that the cyst is a pathology with well defined characteristics, where it presents a pathological cavity coated by an epithelium containing in its interior a liquid or semisolid, even gaseous material. Conclusion: The root cyst can reach large proportions when not treated or discovered late, mainly because it is a pathology that does not present painful symptomatology in initial conditions unless it is infected.

Copy Right, IJAR, 2018,. All rights reserved.

\section{Introduction:-}

Periapical lesions correspond to an immune reaction to bacterial aggression through the release of toxins as a product of bacterial metabolism. Due to pulp necrosis, the dead pulp becomes the perfect environment for the 
proliferation of microorganisms. The formation of lesions derives from a complex process involving a series of intrinsic mechanisms mediated by signaling molecules that will determine the formation of a change in the periápice that may represent several stages of an inflammatory process, among them a root cyst ${ }^{1}$.

The root cyst is a pathological cavity lined by an epithelium resulting from epithelial remains (Malassez) that after odontogenesis remains in place and from an inflammatory stimulus develops. Normally the root cyst is related to a necrotic tooth, presenting: pulp gangrene, resulting from a stimulation of the epithelial remains by means of inflammation. The cysts reflect the last stage in the process of progression of inflammatory occurrences, secondary to the pulp necrosis of a dentin element, in turn defined as a pathological cavity that is surrounded by a coating epithelium, containing in its interior a liquid, semi- solid even gaseous ${ }^{2}$.

Cystic lesions may affect both the maxilla and the mandible, representing 52\% to $68 \%$ of all cysts affecting the oral cavity in individuals between the second and fourth decade of life and the majority of the patients do not present symptoms, that is demonstrated by the fact that virtually all root cyst originates from preexisting periapical granulomas, clinically we have teeth without pulp vitality and a well defined radiolucent area associated with the apex or lateral region of the involved tooth; however in some cases it may present a slight sensitivity or pain when the lesion is exacerbated ${ }^{3}$.

When radiographically the lesion is rounded or oval, unilocular, sclerotic margins, dislocation and dentin resorption, radiolucency associated with the apex of the tooth without vitality and with the hard lamina already ruptured, there is a strong suspicion that it is a root cyst, however the histopathological examination will confirm or discard the hypothesis ${ }^{4}$.

The treatment for the root cyst occurs in several ways, and conservative measures should be prioritized, such as: the endodontic treatment of the devitalized tooth and if there are remnants of recurrence, the same management in question can be repeated, with or without apicoectomy; in cases that the conservative treatment was not satisfactory, surgical maneuvers may be available, such as extraction of the dental unit followed by periapical curettage, marsupialization in cases that it is necessary to reduce the cystic cavity, decompression or cystic enucleation ${ }^{5}$.

The objective of the present study is to report a clinical case of a successful treatment, related to the removal of a radicular cyst in the anterior region of the maxilla.

\section{Methodology:-}

A bibliographic search was performed in the main databases: PUBMED (www.pubmed.gov); ScIELO (www.scielo.org), Google Scholar (www.scholar.google.com.br), BVS (http://bvsalud.org/) e LILACS (http://lilacs.bvsalud.org), which we collected papers that were published from 2002 to 2017. It included laboratory studies, case reports and systematic reviews as well as literature that were developed in the human species and, therefore, articles that did not deal with the management were excluded rehabilitation of root cysts, even if it did not involve the pathology itself.

Through the bibliographic research, 33 articles were selected, all of which were extracted from: PUBMED (www.pubmed.gov); ScIELO (www.scielo.org) , Google Scholar (www.scholar.google.com.br), BVS (http://bvsalud.org/) e LILACS (http://lilacs.bvsalud.org), previously reported (FLOWCHART.1 and GRAPH.1). The following titles of specific medical subjects and keywords were used: Radicular Cyst ([MeSH Terms]); Pathology, Oral ([MeSH Terms]); Odontogenic Cysts ([MeSH Terms]); Surgery, Oral ([MeSH Terms]). 
Flowchart 1:- Flowchart of the criterion of inclusion of articles.
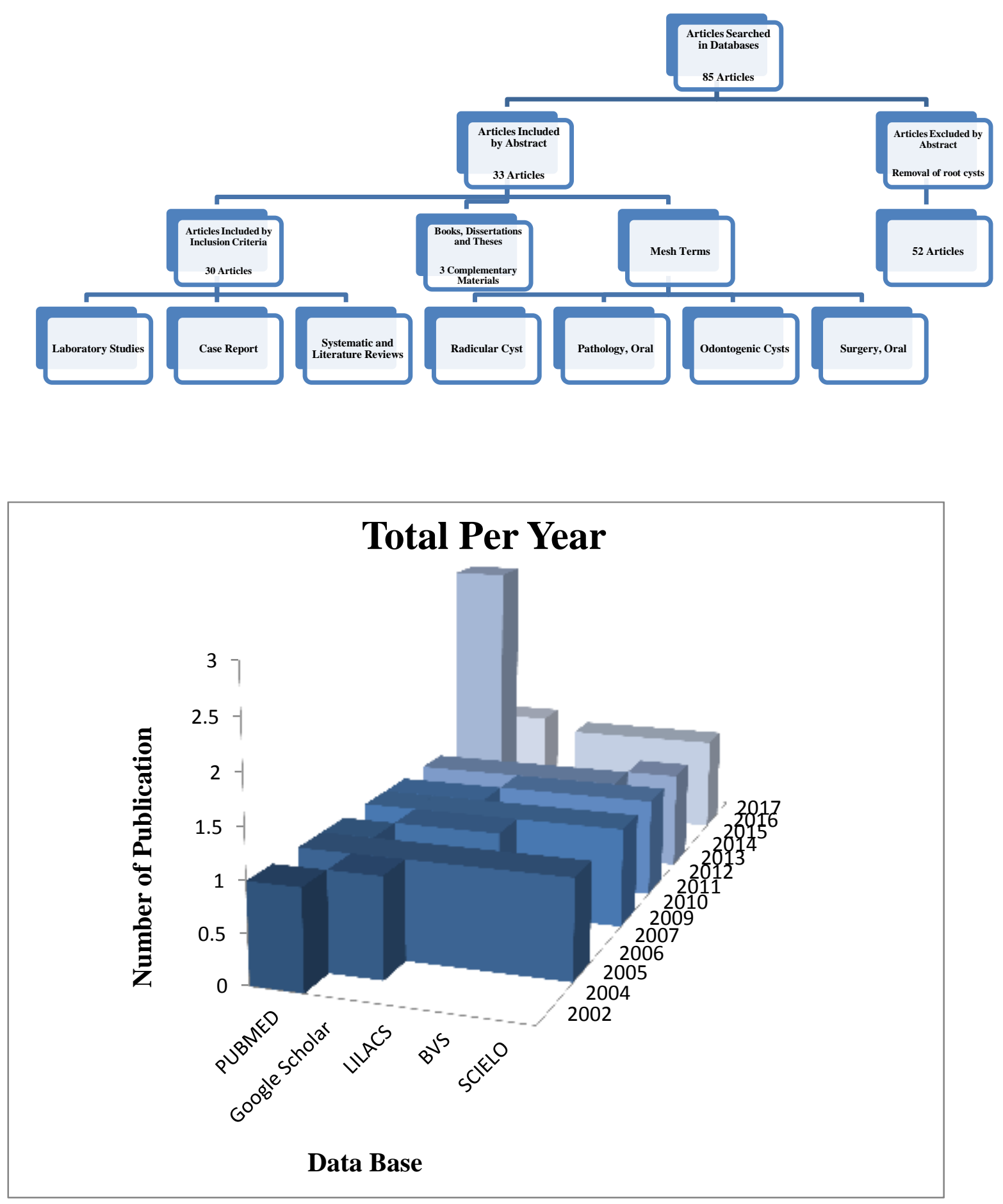

Graph 1:- Cumulative Graph. 


\section{Results:-}

Through the review, all studies showed that the cyst is a pathology with well defined characteristics, where it presents a pathological cavity coated by an epithelium containing in its interior a liquid or semisolid, even gaseous material; the appearance of the same is probably related to the epithelial residues that remain in the region during the dental formation process and along the lines of fusion of the maxillary bones in embryogenesis, and may or may not be associated with pathological inflammatory processes (Table 1$)^{6}$.

The epithelial remnants, by unknown stimuli, proliferate forming islet cells that, because they have insufficient nutrition, caused by the distance of the adjacent connective tissue, favor the degeneration of the central cells, which by enzymatic action liquefy. In this liquid, we find high protein concentration, as well as cholesterol crystals, which generates high osmotic pressure. The cystic capsule functions as a semipermeable membrane, bringing fluid from the tissue spaces into the lesion, until the hydrostatic equilibrium is established ${ }^{7}$.

The cystic lesion presents a slow and continuous growth, passing through four well-defined evolutionary phases, namely: Silent: without clinical manifestation, usually found in routine radiographic examination, which makes it imperative to request a panoramic radiograph to every client of first consultation ; Deformation: bulging of the cortical bone resulting from lesion growth is more easily noticed in the maxilla than in the mandible, due to the smaller thickness of the maxillary cortices, offering less resistance to expansion; Externalization: increased deformation, with thinning of the cortical bone, and its rupture may occur at the most prominent point, which allows the digital pressure to feel the compression of a "PING-PONG" ball, also called crackling signals. And lastly not least the infection: by communication with the oral cavity, through the periodontium or possibly hematogenously, the cyst undergoes an acute infectious process of great repercussion and rapid evolution, requiring immediate intervention with antibiotic medication and drainage ${ }^{8-10}$.

Cysts of inflammatory odontogenic origin caused by inflammation or trauma are those commonly found in the clinical routine of the dental surgeon. Radicular cyst is a radiopaque lesion arising from a pulpal lesion caused by caries or trauma. Its origin is related to a periapical granuloma, which is mostly asymptomatic unless there is an exacerbated inflammatory response of infectious origin. The root cysts have their highest incidence in individuals between the second and fourth decade of life by male predilection and its higher incidence occurs in the anterior region of the maxilla ${ }^{11}$.

Radiographically the radicular cyst is identical to the apical granuloma and it is possible to confirm that it is a root cyst by histopathological examination. The size of the lesion and its radiolucency can not be used as definitive diagnosis. Although in the radiographic examination it is possible to observe the loss of the hard lamina along the root and a round radiolucency associated with a devitalized tooth; Large periapical cysts may involve a whole quadrant, promoting direct tooth mobility. Before histopathological examination, a non-keratinized stratified squamous epithelial lining can be observed and its thickness may vary ${ }^{12}$.

The periapical cyst if untreated can reach considerable size causing expansion of the cortical bone with hard and painless swelling. When the cortical bone is ruptured due to its growth, the lesion becomes soft to palpation of cystic or fluctuating consistency. When the pathology reaches a considerable size and ruptures the cortical bone, the cyst is exteriorized, this exteriorization may involve vestibular or palatal region depending on the tooth and the root angulation in which the cyst is associated; already in the jaw its exteriorization is almost in its totality for vestibular $^{13}$.

The diagnosis for this pathology is closed after anamnesis, clinical characteristics, radiographic examination and histopathological examination; complementary measures can still be performed as the aspiration puncture examination, where before the maneuver in question aspiration the content harvested is brownish or citrus with bright spots $^{14}$.

The treatment for the root cyst according to the literature consists of the exodontia of the element associated with the lesion with a careful curettage, enucleation, marsupialization or the endodontic treatment of the element followed by apicectomy and enucleation of the cystic lesion. in consideration that one must always follow a line of logical reasoning, first the most conserved treatment, if there are no satisfactory results the less conservative ${ }^{15}$. 


\begin{tabular}{|c|c|c|c|}
\hline Author / year & Kind of study & Case Numbers & Treatment / Conduct \\
\hline Peixoto RF; Peixoto DF., $2012^{1}$ & Analytical & - & Surgical Excision \\
\hline Mendonça DWR et al., $2017^{2}$ & Case Report & 1 & Enucleation \\
\hline Neville BW et al., $2009^{3}$ & Analytical & - & Enucleation \\
\hline Martins-Filho et al., $2009^{4}$ & Case Report & 1 & Marsupialization \\
\hline Dantas RMX et al., $2014^{5}$ & Case Report & 1 & Enucleation / Apicectomy \\
\hline Vasconcelos $R G$ et al., $2012^{6}$ & Case Report & 1 & Decompression \\
\hline Feix LM et al., $2010^{7}$ & Analytical & - & Microscopic Endodontics \\
\hline Neto $M M$ et al., $2004^{8}$ & Literature Review & - & Enucleation \\
\hline D’Adazzio PSS et al., $2010^{9}$ & Case Report & 1 & Apicectomy \\
\hline Garib DG et al., $2007^{10}$ & Analytical & - & Tomography Cone Beam \\
\hline Carvalho MGP et al., $2005^{11}$ & Case Report & 1 & Apicectomy \\
\hline Pozzer L et al., $2009^{12}$ & Case Report & 1 & Decompression \\
\hline Alves IFS et al., $2016^{13}$ & Case Report & 1 & Enucleation \\
\hline Arieta LC et al., $2005^{14}$ & Comparative & 1 & Radiographic \\
\hline Silva MP et al., $2016^{15}$ & Case Report & 1 & Endodontic Retreatment \\
\hline Cavalli D et al, $2014^{16}$ & Evaluator & 1 & AgNORS Technique \\
\hline Azambuja $T$ et al., $2014^{17}$ & Literature Review & - & Surgical Treatment \\
\hline Secco M; Burzlaff JB, $2011^{18}$ & $\begin{array}{l}\text { Multidisciplinary } \\
\text { Review }\end{array}$ & 1 & Enucleation \\
\hline Politano GT et al, $2009^{19}$ & Case Report & 1 & Enucleation \\
\hline Silveira EJD et al, $2007^{20}$ & Evaluator & 1 & Etiopathogenic \\
\hline Oliveira $D$ et al , $2011^{21}$ & $\begin{array}{lcl}\text { Case } \quad \text { Report } & \text { and } \\
\text { Literature Review } & \\
\end{array}$ & 1 & Enucleation \\
\hline Pereira JS et al, $2012^{22}$ & Case Report & 1 & Enucleation \\
\hline Oliveira $M$ et al, $2002^{23}$ & Evaluator & 1 & Immunohistochemical \\
\hline Tijoe KC et al , $2015^{24}$ & Case Report & 1 & Enucleation \\
\hline Igreja FF et al, $2005^{25}$ & Case Report & 1 & Marsupialization \\
\hline Utumi ER et al, $2012^{26}$ & Case Report & 1 & Surgical Excision \\
\hline Colombo CED et al , $2005^{27}$ & Epidemiological & 1 & Histopathological Reports \\
\hline Pinto SIT et al, $2016^{28}$ & Evaluator & 1 & Endodontic \\
\hline Santos LCS et al, $2006^{29}$ & Case Report & 1 & Surgical Excision \\
\hline Signoretti FCG et al, $2013^{30}$ & Evaluator & 1 & Endodontic Retreatment \\
\hline Jardim TH et al, $2015^{31}$ & Case study & 1 & Tomography Cone Beam \\
\hline Moura PM et al, $2009^{32}$ & Case Report & 1 & Maxilla Expansion \\
\hline Junqueira RB et al, $2011^{33}$ & Case Report & 1 & Computed Tomography \\
\hline
\end{tabular}

- not reported by the author.

Table 1:- Results presented by the author's approaches

\section{Case Report:-}

Patient D. F. R, female, feoderma, 26 years old, sought clinical symmetry, referred by an endodontist, requesting apicectomy and enucleation of a root cyst. During the anamnesis, the patient reported that she had sought a private clinic for endodontic retreatment, since the first treatment was unsuccessful. A pulp vitality test was performed, verifying the non-vitality or absence of the coronary pulp, a percussion test was presented with a slight sensitivity, palpation test of the periapical positive.

Ahead the examination of crown inspection it was possible to observe extensive fracture restoration and still with diffuse caries, and with presence of fistula in a soft tissue regimen. The radiographic examination revealed unsatisfactory fillings, diffuse bone resorption and interrupted hard lamina; a periapical lesion was noted in the periodontium; confirming the diagnosis of pulpal origin of necrosis, and the chronic alveolar abscess periodontal periodontal, being basically a chronic process with focus of suppuration located near the perirradicular region of a root canal of necrotic pulp.

The affected elements were 11, 21 and 22; In this way, the endodontic retreatment was performed by means of endodontic microscopy, which in turn provides a wealth of detail, easy documentation of the clinical case, 
complements the tomographic examination, allows the refinement of the channels, if there is presence of calcification in the canal, it is possible to detect, the ability to visualize and treat isthmus, ultrasonic reinstrumentation, removal of fractured instruments within the canals from accidents, corono-radicular perforations, accurate diagnosis of fractures, among others (Figure 1).

Endodontic retreatment was performed as follows: initially anesthesia was used with the use of the anesthetic mepivacaine 2\% + epinephrine 1: 100,000, after the anesthetic had achieved the absolute insulation and access of the teeth in question, the odontometry of the region of 11 in which it presented a single channel, with reference in the incisal, presenting $24 \mathrm{~mm}$, the working length $(\mathrm{CT}): 23 \mathrm{~mm}$; in the region of 21 the odontometry was $23 \mathrm{~mm}$ and the CT was $22 \mathrm{~mm}$, whereas the region of odontometry was $19 \mathrm{~mm}$ and the CT was $18 \mathrm{~mm}$ (Figure 2, 3 and 4). The initial instrumentation was done with file \# 50 by the Crown - Down technique and the Final Lima (LF) was \# 110, this in the region of 11; in Element 21 the Initial Lime (L1) was \# 45 and LF \# 80, and in L1 \# 45 and LF \# 70 (Figure 5 and 6). Irrigation of the three channels was done with sodium hypochlorite solution 5.0\%, Ethylenediaminetetraacetic acid chelator (E.D.T.A) $17 \%$ for 5 minutes, final solution of physiological saline, allowing ultrasound agitation CUI and foraminal enlargement of the three elements in question. A dressing of Calcium Hydroxide (HC) was placed for 7 days and its extension was intracanal and shielded with glass ionomer, it is worth noting that in the region of 11 there is an absence of intracanal drainage (Figure 7).

After 7 days, the elements were again irrigated and their channels were irrigated, and then a lateral and vertical condensation technique was applied, using single cones Downpack + Backfill (Buchanan), using gutta-percha materials, and cementing with the ENDOFILL® sealing cement, its extension at the CDC boundary, apical puff (Figure 8 and 9). With this, there is a dentin qualification plus the cervical resin shielding and the final composite resin restraint of the region of the three elements elucidated previously (Figure 10).

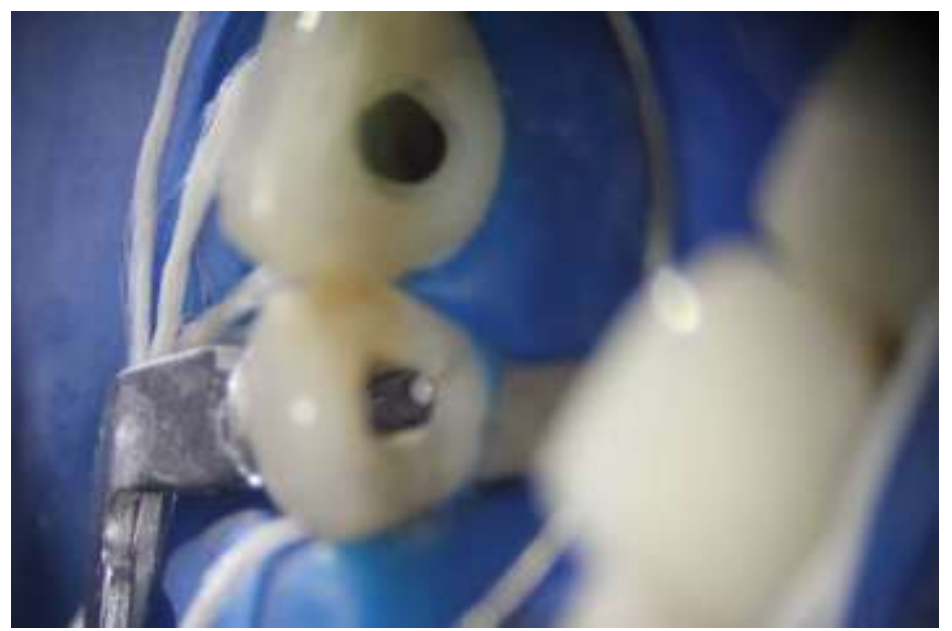

Figure 1:- Opening of root canals.

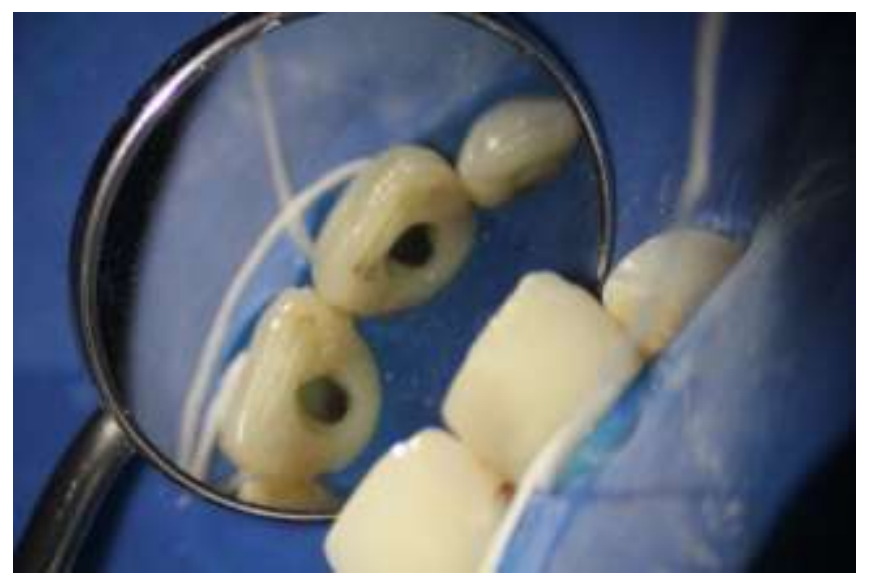




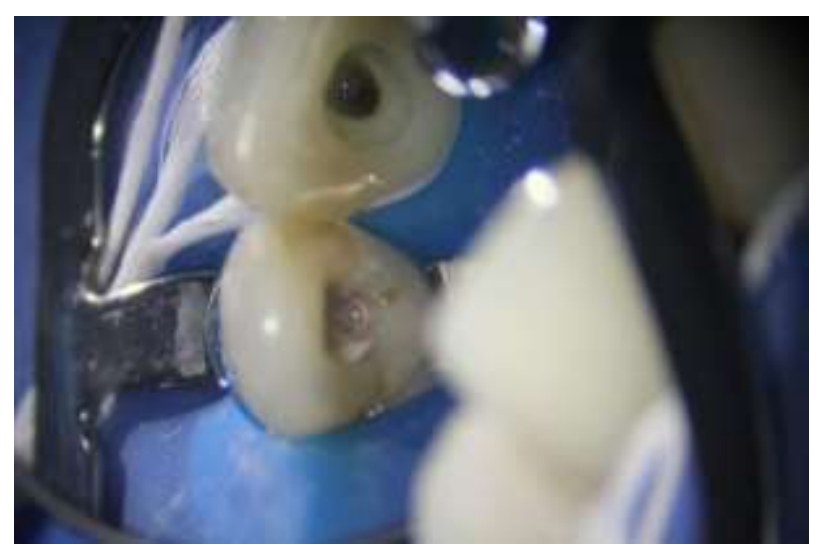

Figure 2 and 3:- Failed endodontic treatment.

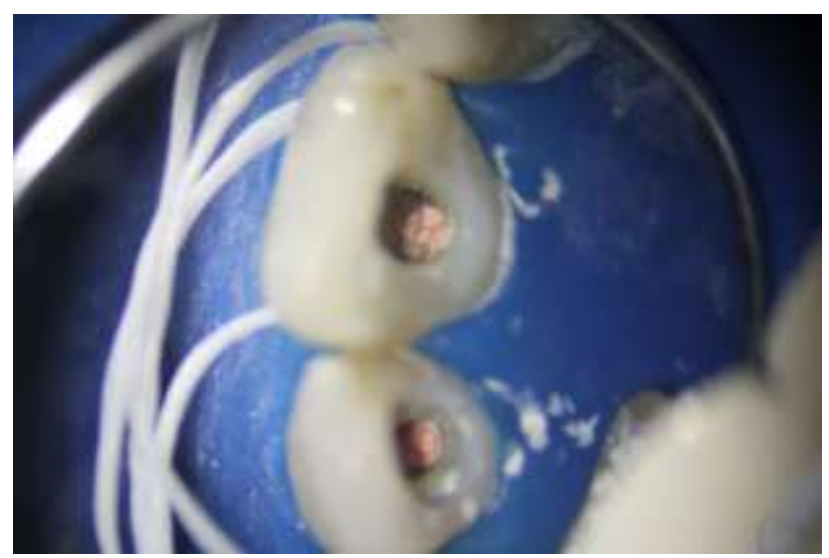

Figure 4:- Gutta percha present in canal treated improperly.

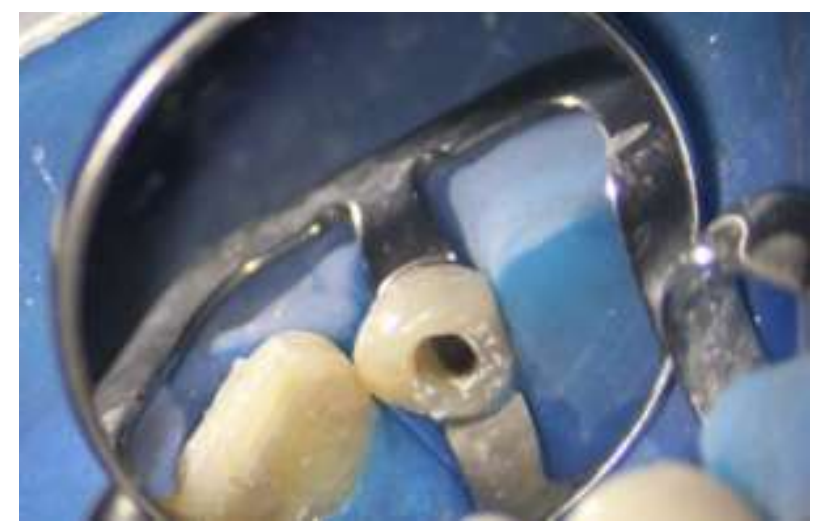




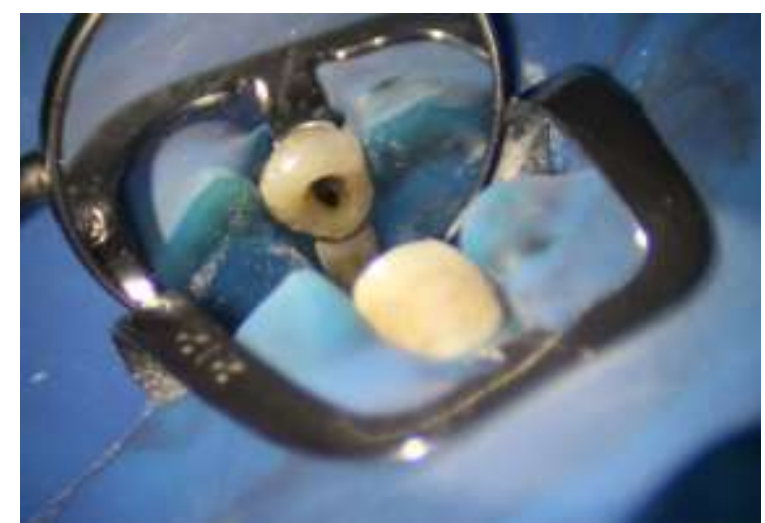

Figure 5 and 6:- Unsatisfactory fill removed.

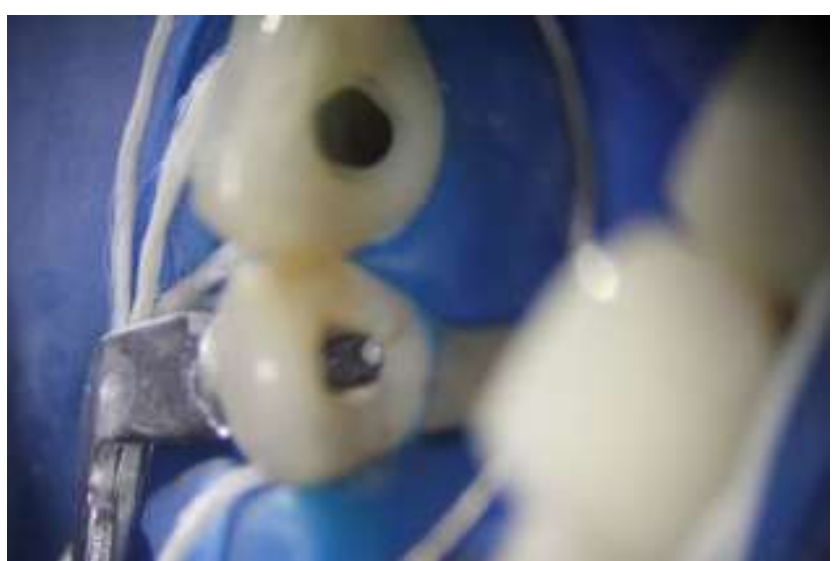

Figure 7:- Channel with intracanal dressing of calcium hydroxide in the bottom of the conduit.

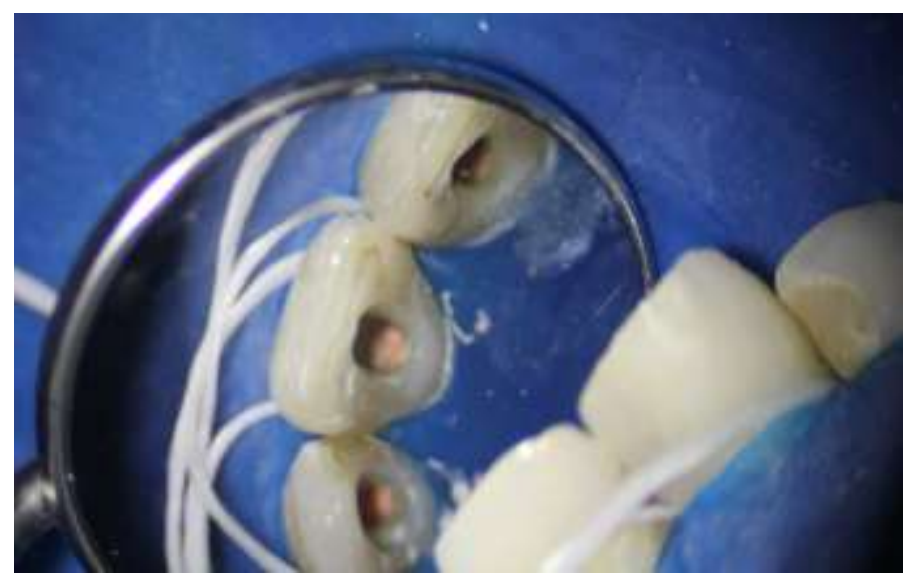




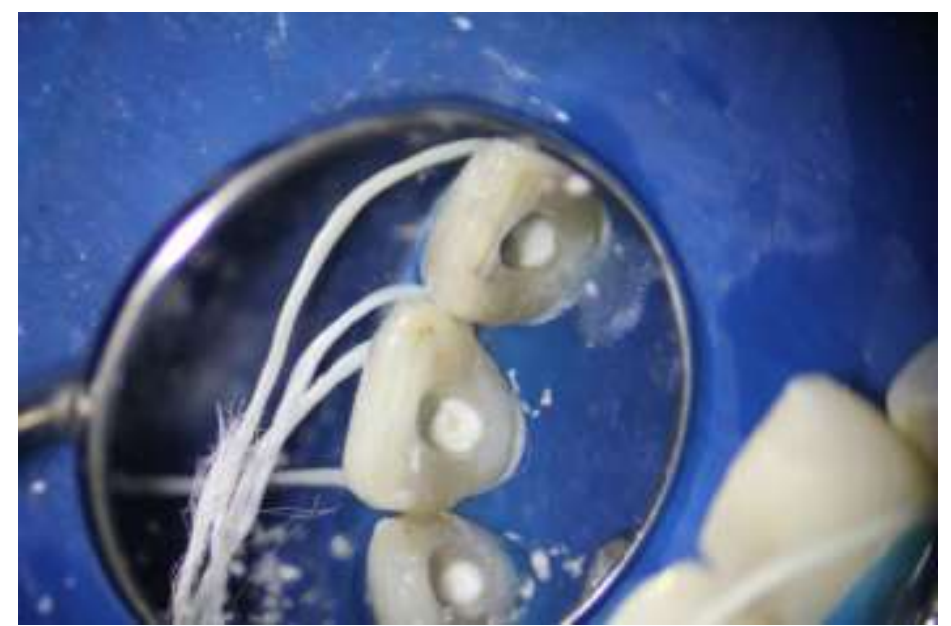

Figure 8 and 9:- New filling with retreatment already performed.

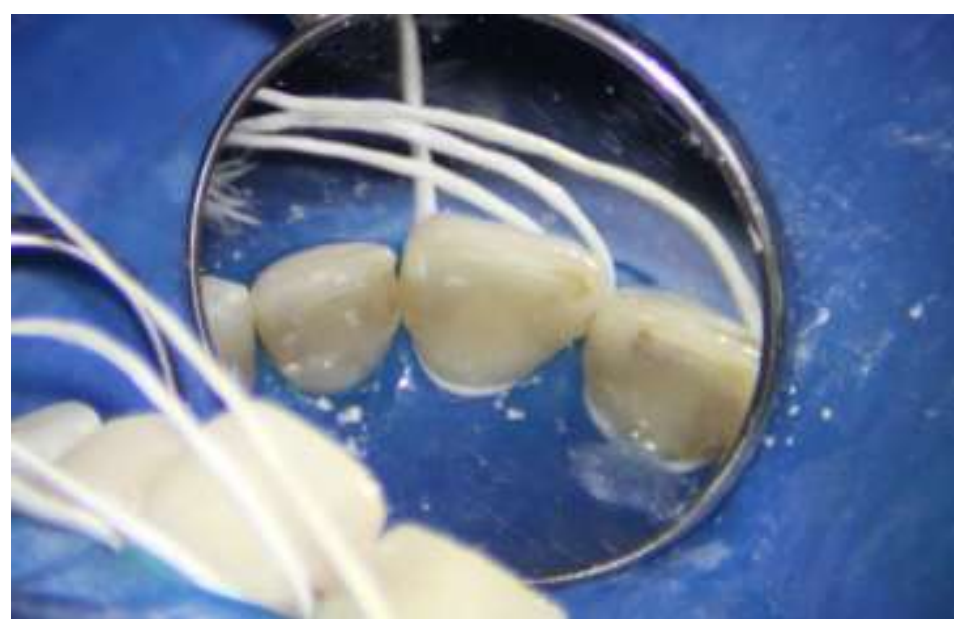

Figure 10:- Definitive restoration with composite resin and cervical shielding.

For the removal of the pathology at the bone level, other radiographic examinations were requested to support the diagnosis and to obtain the best treatment. In this specific case: cone beam computed tomography (CT), revealing a hypodense, unilocular area with a hyperdense, circumscribed halo; involving the dentinal apices of elements 11, 12, 13, 21 and 22. With close contact of the lateral wall of the nasal fossa on the right side, there being expansion of the buccal and palatine cortical bone in the axial section, still intrinsically touching the nasopalatine nerve. The radiographic report issued by the radiologist stated that it was a periapical lesion of an inflammatory character, because it is directly related to the root apex. 


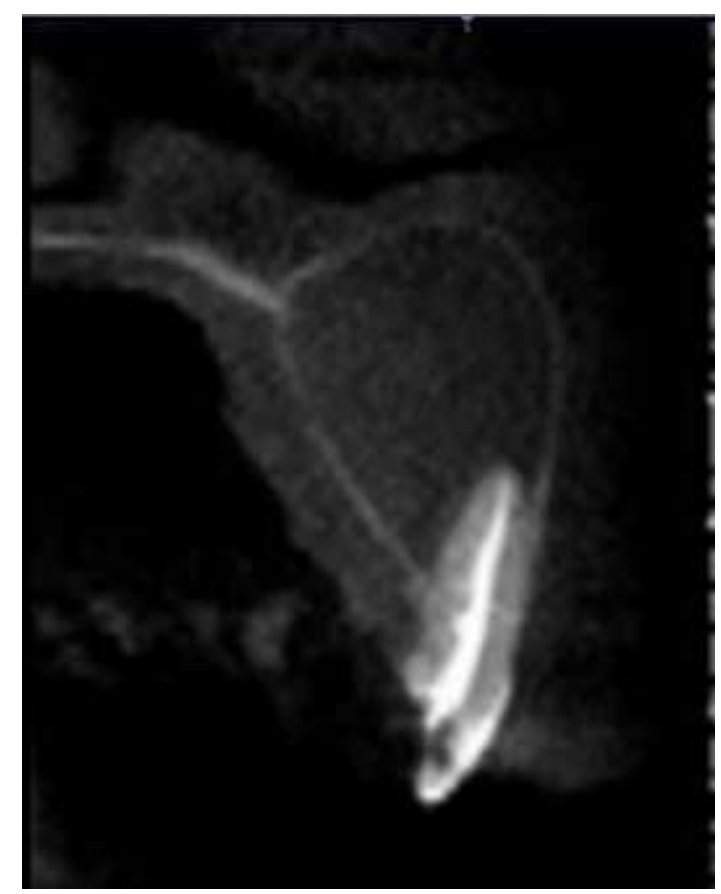

Figure 11:- Tomographic of the lesion.

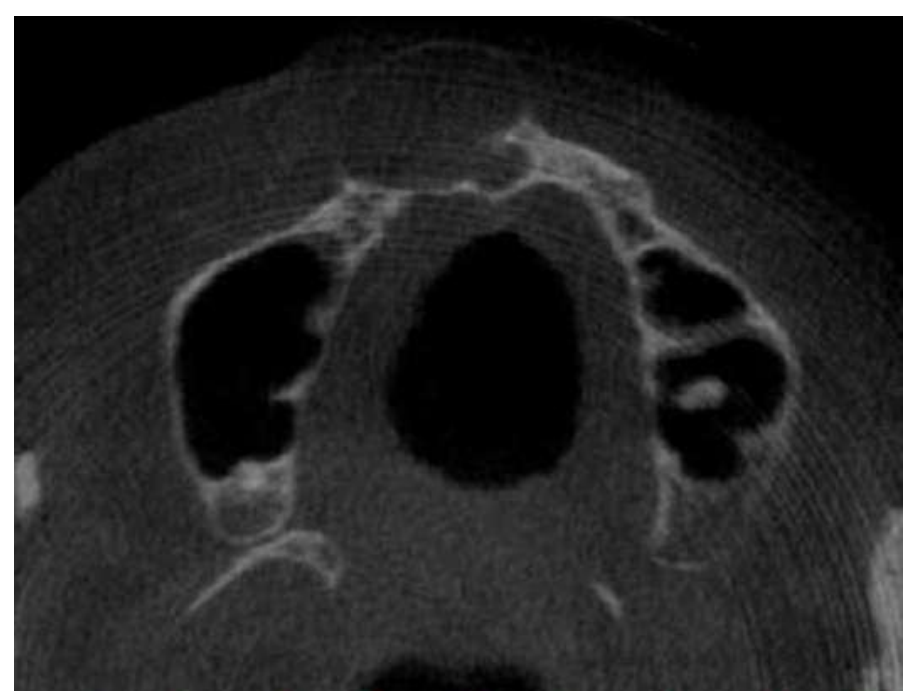

Figure 12:- Axial image of the lesion.

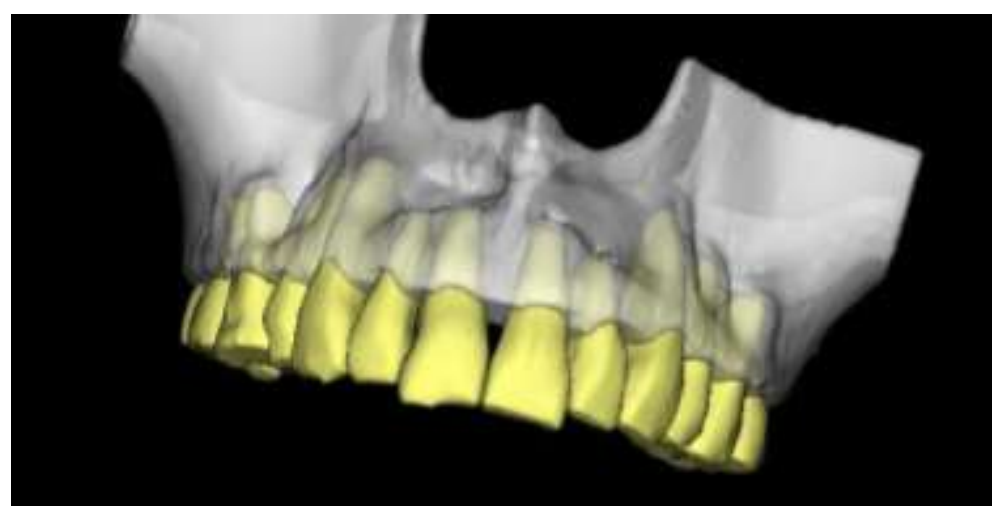

Figure 13:- 3D reconstruction emphasizing anterior bone resorption of the maxilla (angled). 


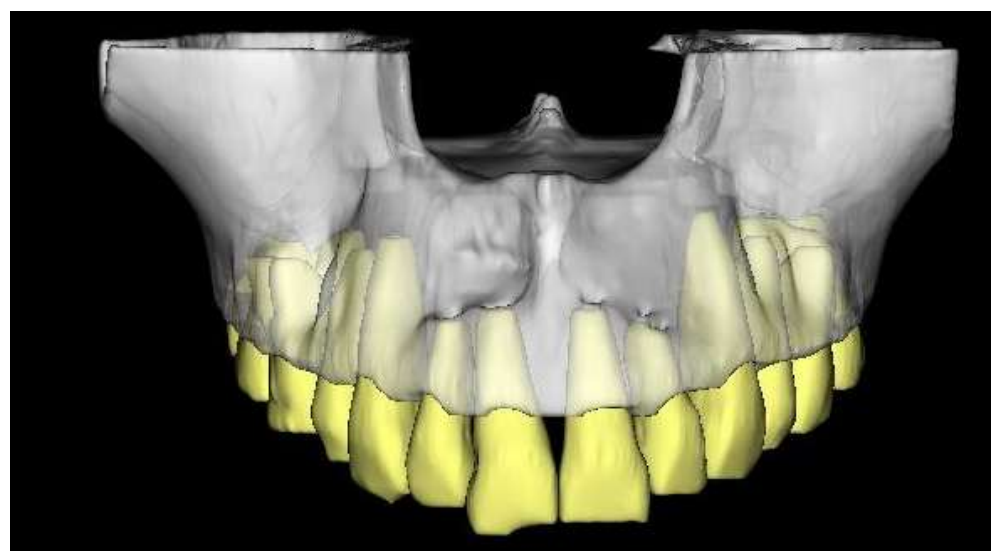

Figure 14:- 3D reconstruction emphasizing anterior bone resorption of the maxilla (parallel to the ground).

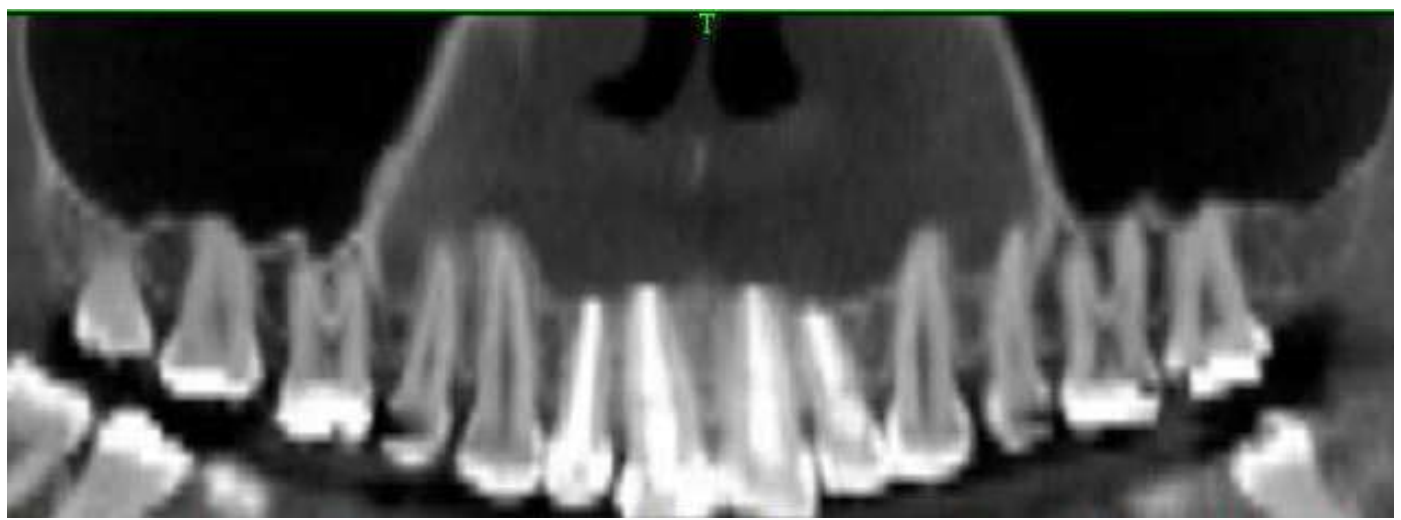

Figure 15:- Panoramic showing radiolucent lesion associated with the apices of elements 13, 12, 11, 21 and 22.

Complementary preoperative tests were also requested: Complete blood count, Coagulogram, TP (Prothrombin time), APTT (Activated partial thromboplastin time), Fasting glycemia.

Faced with clinical and radiographic findings, an excisional biopsy was performed as ordered by the clinical protocol. Placed in a container containing $10 \%$ formaldehyde previously identified, was sent for histopathological examination. The histopathological report showed soft tissue fragment of firm consistency and covered by a fibrous capsule of irregular shape and surface with hemorrhagic remnants and non-keratinized squamous epithelium measuring $2.0 \mathrm{~cm} \mathrm{X} 1.5 \mathrm{~cm}$.

An aspiration puncture was also performed with a $20 \mathrm{ml}$ syringe to check the content present in the intraosseous lesion. The fluid found inside the lesion was cloudy, light brownish with bright spots.

The treatment of the cystic lesion consisted of an apicectomy and enucleation, where it began by performing an intra-buccal incision with apical repositioning flap because it is an esthetic region with mucoperiosteal folding extending from the mesial of element 15 to the mesial of element 22 Followed by an osteotomy of the buccal bone plate to access the lesion under constant irrigation based on saline solution (Figs. 16 and 17) to perform enucleation of the aforementioned lesion (Figures 18 and 19). After enucleation, the cavity was curetted with Lucas serrated curettes $n^{\circ} 01$ and 02 Welfare. 


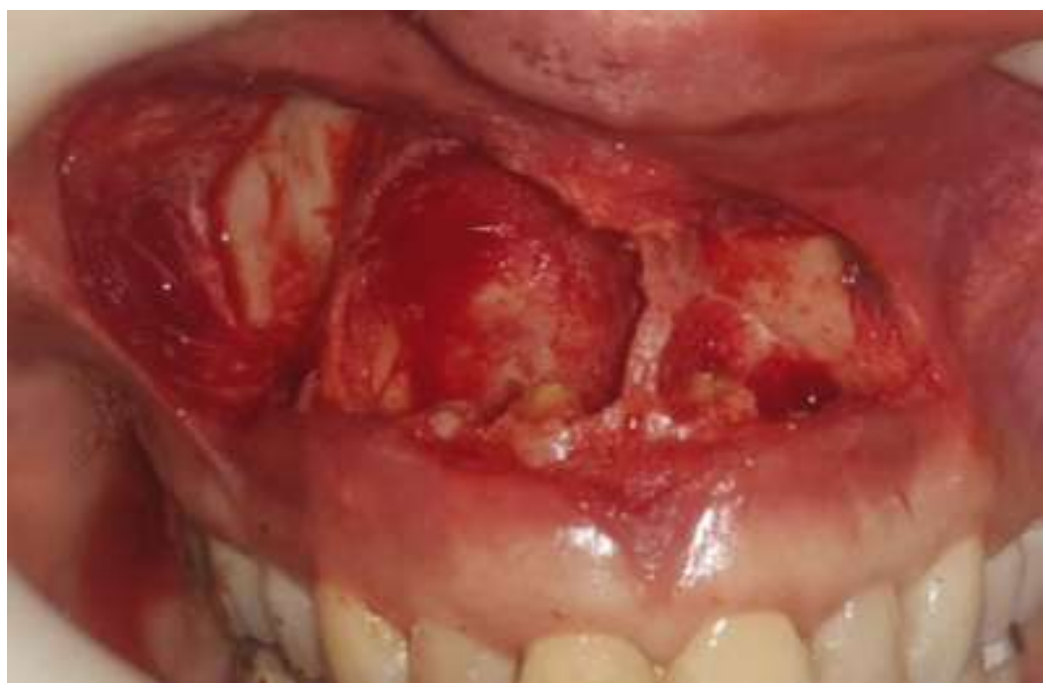

Figure 16:- Bone shop for access to injury.

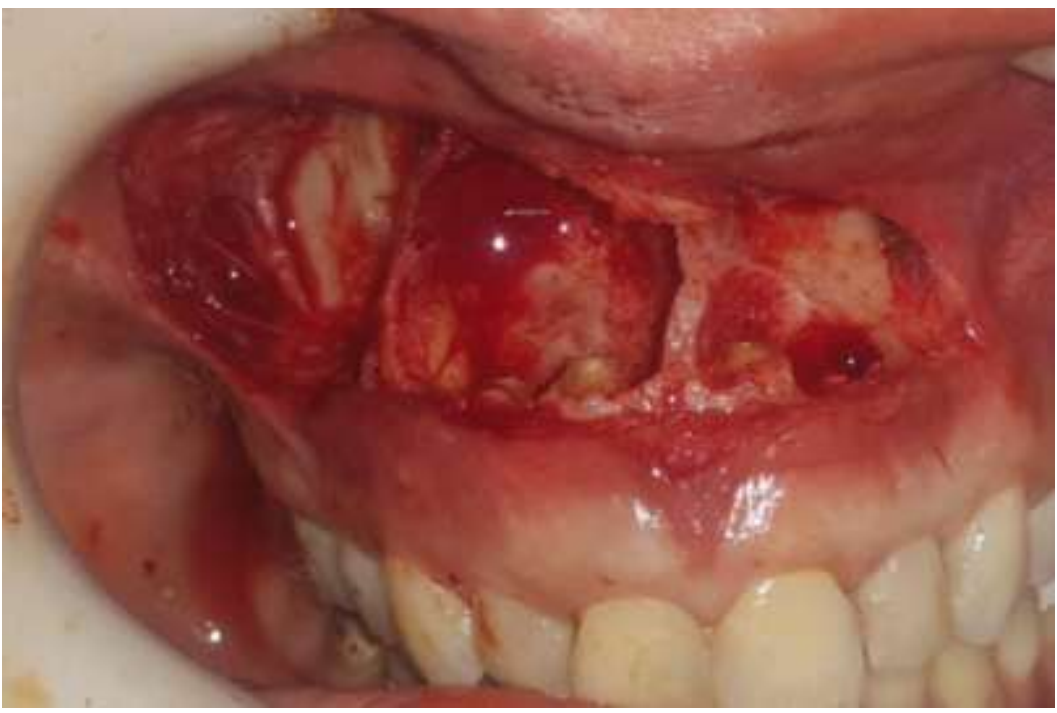

Figure 17:- Access to bone lesion by vestibular (osteotomy).

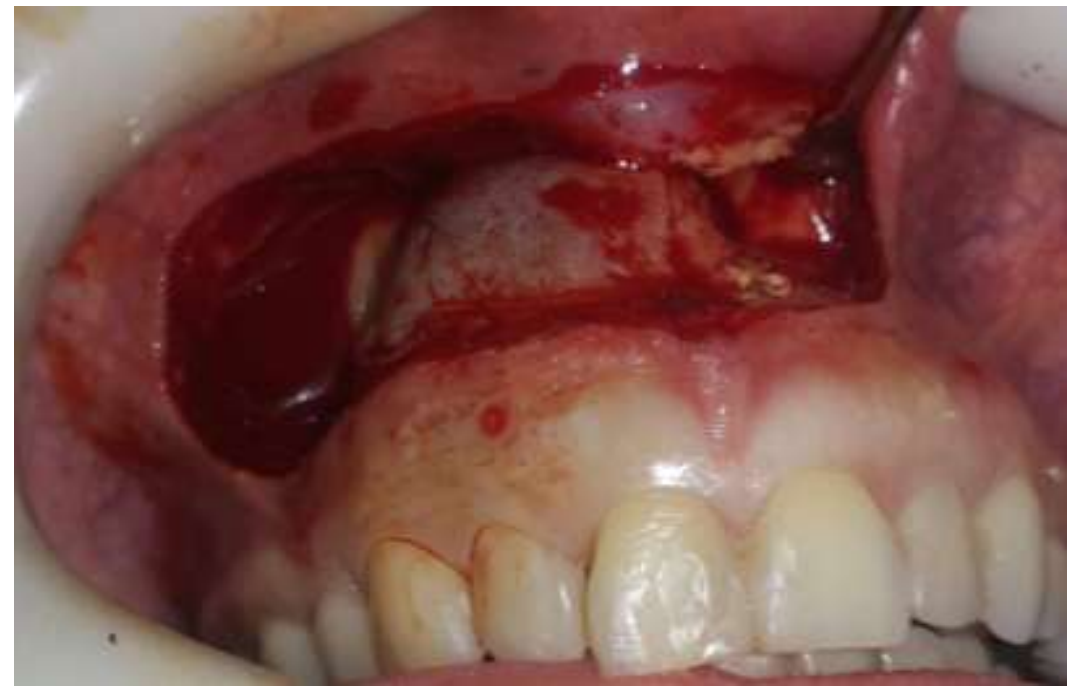

Figure 18:- Enucleation of the radicular cyst. 


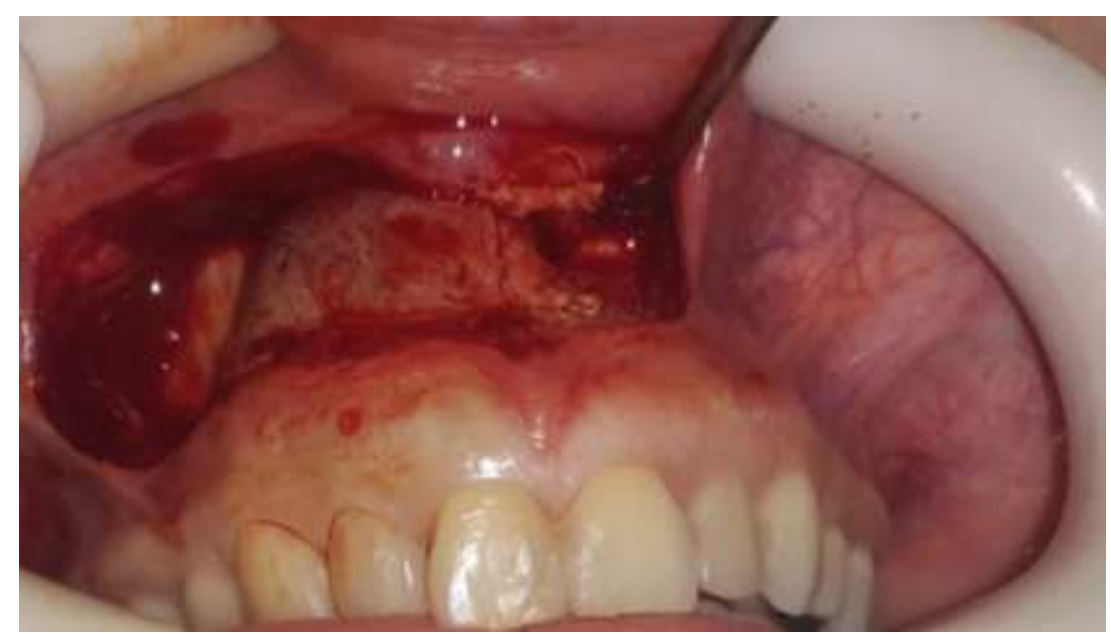

Figure 19:- Surgical removal of the root cyst.

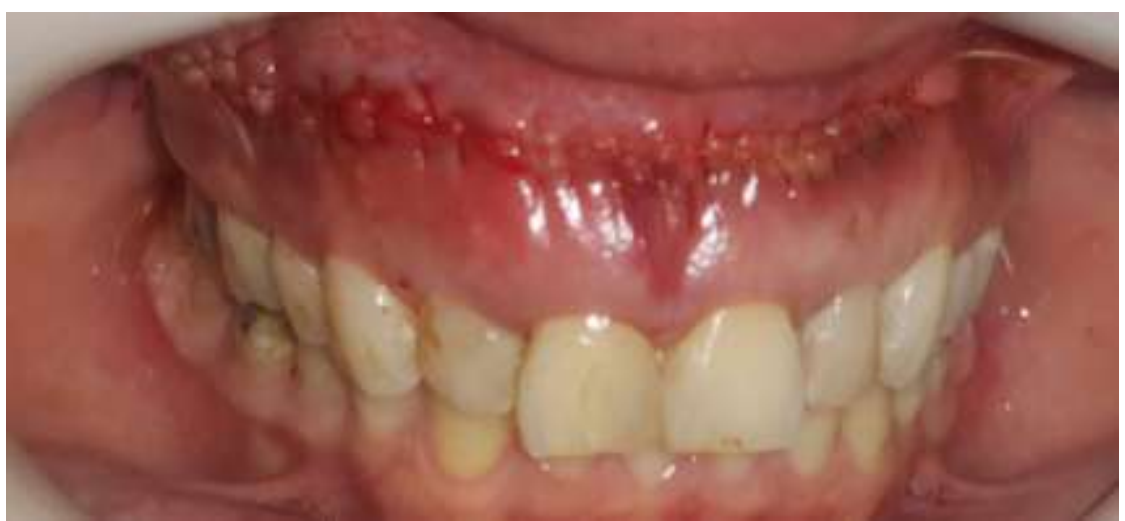

Figure 20:- Suture of surgical wound after repositioning of the flap.

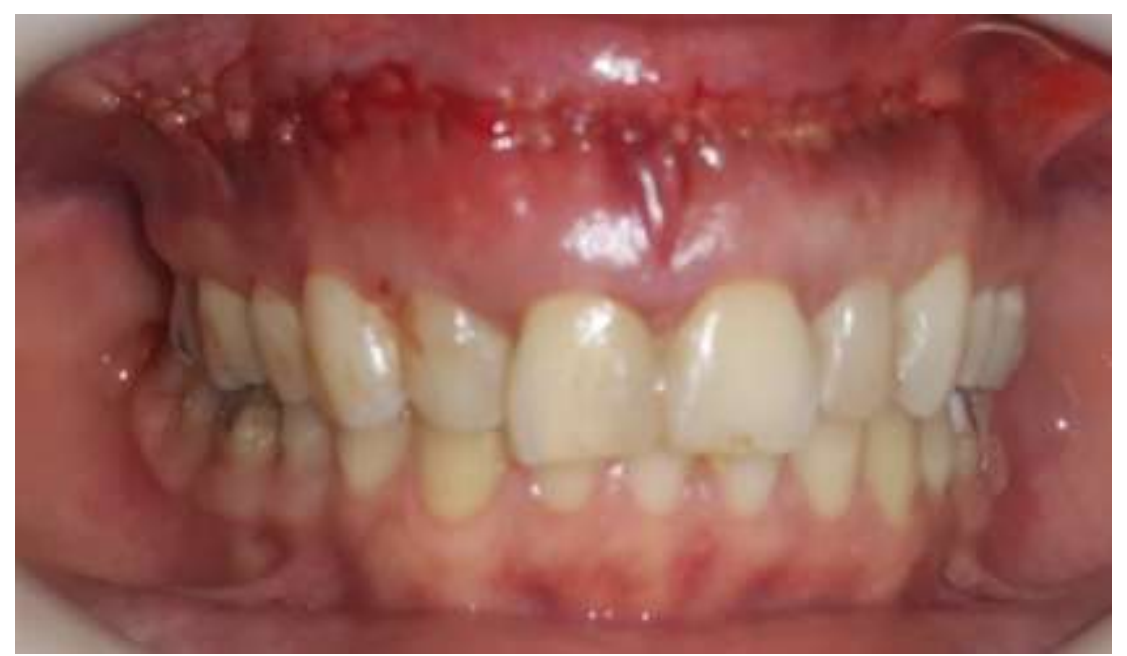

Figure 21:- Suture using absorbent wire vicryl - ethicon (E-15) no ${ }^{\circ} 4.0 / 16 \mathrm{~mm}$.

After the entire surgical procedure, the flap was repositioned and sutured at continuous points anchored using adequate and efficient vicryl - ethicol (E - 15) suture strand No. $4.0 / 16 \mathrm{~mm}$ (figures 20 and 21). The case was followed closely and 180 days after the removal of the lesion, new tomographic examinations were performed observing that the patient gained large bone proportions in both width and dimension (figures 22, 23, 24 and 25). 


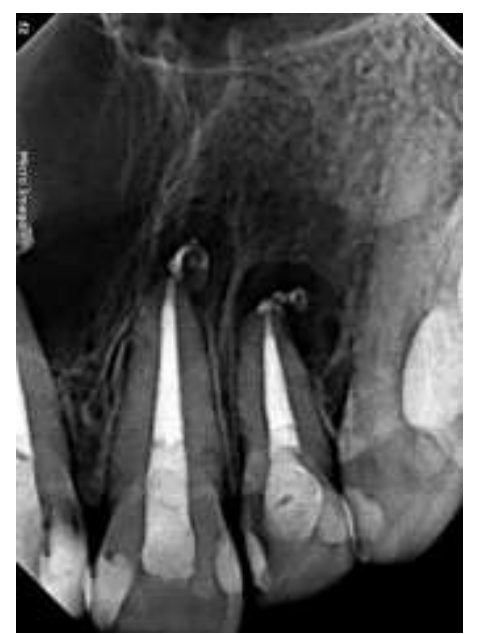

Figure 22:- Periapical X-ray showing lesion associated with the tooth apex.

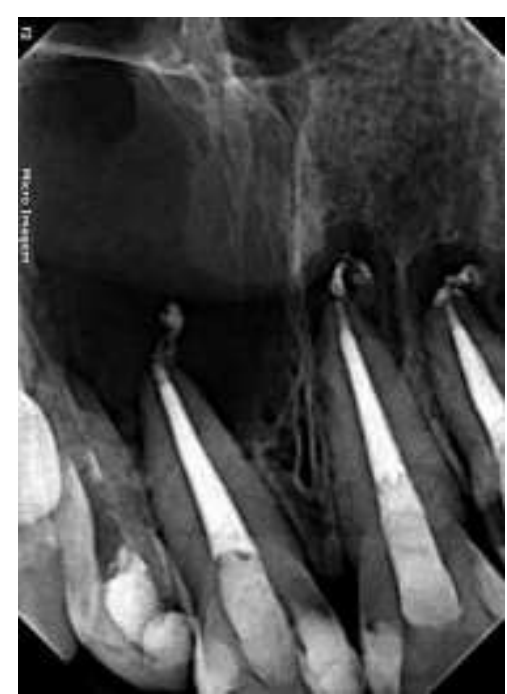

Figure 23:- X-ray after retreatment showing extravasation of gutta percha.

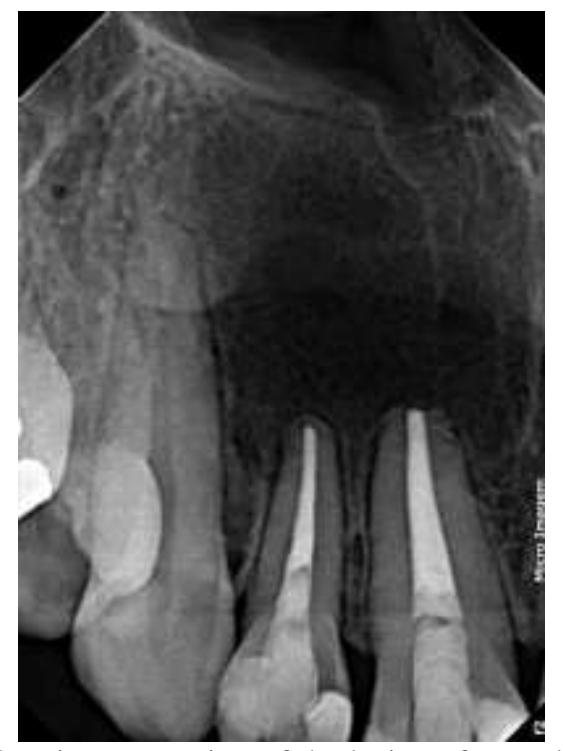

Figure 24:- X-ray showing regression of the lesion after endodontic retreatment. 


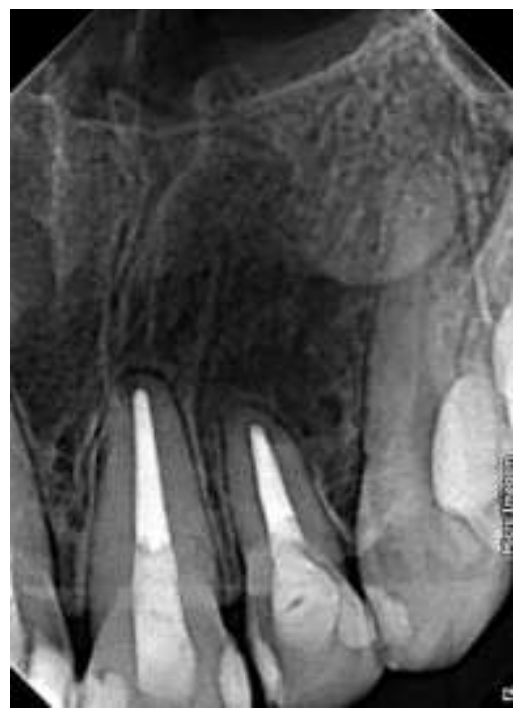

Figure 25:- X-ray evidencing bone neoformation after 6 months of treatment.

At the clinical examination the patient remains with tissues and mucous membranes within normality and will continue to be followed up for a considerable period by performing radiographic examinations every 06 months.

\section{Discussion:-}

Inflammation is a protective response of the body against an aggression, whose purpose is to rid the body of the aggressor agent and the consequence of this aggression, in turn a reaction of the blood vessels, leading to an accumulation of extravascular tissue and leukocytes; through a mechanism of tissue defense occurs rupture of hemostasis and mobility of substances and cells ${ }^{16}$.

This inflammation in turn promotes a microcirculation of the region and a vascular reaction in which it generates plasma exudation and cellular transmigration, allowing the release of chemical mediators and lymphocytes macrophages and plasma cells. Pain increases tissue pressure, causing pulpal hyperemia and edema, with release of pain-producing inflammatory agents such as bradykinin, bradykinins stimulates amyloin type C17 fibers ${ }^{17}$.

A lesion in peri-penice region due to an inflammation at the dental apex caused by the toxin released as a product of the bacterial metabolism that colonizes the pulp and the root canals of necrotic elements; being directly related to chronic inflammation due to an injury, caused by a low virulence infection, long duration and persistent aggression $^{18}$. The chronic inflammatory process allows the formation of a vascularization of its own (angiogenesis), mononuclear infiltrate and fibroblasts; after 24 to 72 hours the presence of B lymphocytes, more specifically plasma cells and also $\mathrm{T}$ lymphocytes in this case (Helper, cytotoxic and NK), finally cytokines ${ }^{19}$. Macrophages with the presence of multinucleated, phagocytic cells, presenting antigens and cytokines; productive and proliferative phenomena resulting from fibroblasts and neovascines; even more so than the apical region has the almost unlimited capacity of defense by the presence of the rich vascularization ${ }^{20}$.

The intraosseous lesion evolves from a granuloma originating from an infection located inside the root canals; in some cases the development of this lesion is based on a failure of endodontic treatment, often linked to the failure of endodontic therapy with failure, either in the cleaning and shaping of root canals or during obturation ${ }^{21}$. An endodontic treatment that has failed to lead to a bacterial proliferation and inflammation generated at the dental apex resulting in a peri-penis lesion known as a periapical or radicular cyst ${ }^{22}$.

Endodontic treatment consists of cleansing and mechanical-mechanical debridement of the root canals with the intention of eliminating the bacterial biofilm and the microorganisms present inside these conduits as a result of pulpal necrosis ${ }^{23}$. When this treatment fails, retreatment is indicated and if not performed, the toxins released by these microorganisms force the body to defend itself by limiting its action, forming for this a pathological cavity known as granuloma and in its evolution a cyst around the tooth apex it can form large proportions ${ }^{24}$. 
The endodontic retreatment consists of the removal of the obturator material present in the root canal once treated and performed a new obturation using again cones of gutta percha and endodontic cement. Following the protocol, locking the cone in the stop and 1 millimeter below the radiographic apex for anterior teeth (incisors and canines) and the foramen for posterior teeth (premolars and molars) together with the endodontic cement for retreatment to be successful $^{25}$.

For the retreatment performed in the aforementioned case, endodontic microscopy was used, a resource available to the endodontic professional for the purpose of visual amplification and root canal exploration with greater accuracy. The operative microscope used in endodontics offers great illumination and better visualization of the operative field, which assists in locating calcified channels, detecting microfractures, identifying isthmuses, interpreting the complexities of the root canal system, assisting in the removal of nuclei and allowing a visual amplification up to 20 times ${ }^{26}$.

Most authors in their studies and case reports point out that the root cysts are asymptomatic but that in some cases there may be pain or tenderness when the lesion undergoes inflammation from being chronic and becoming acute. In cases where the lesion takes large proportions, there is swelling present, displacement of the root of the involved and adjacent element, and dental mobility; clinically tests are done as the pulp vitality test (DVT), percussion and palpation $^{27}$.

Radiographically, this lesion presents well defined characteristics: radiopaque, unilocular cavity, associated with one or more non-vital elements, presence of a radiopaque halo delimiting the lesion. The radiographs used to diagnose this type of lesion are usually concomitant CT scans. Mainly computed tomography (CT) is an imaging diagnostic method that uses X-ray and allows the reproduction of a section of the human body in any of the three planes of space $^{28}$. The conical beam or Cone Beam, has a lower than conventional, lower cost tomograph and is suitable for dentomaxillofacial examinations, allowing the multiplanar reconstruction of the scanned contents in which the images are visualized axially, coronal, sagittal and oblique, or it allows the reconstruction of a 3D image ${ }^{29}$.

Histologically, the radicular cyst presents a fibrous connective tissue capsule with a laminated squamous epithelium that covers it and that inside it has a liquid or semi-solid citrus material or light yellow to brown coloration and cellular debris of malassez ${ }^{30}$. Periapical cysts make up approximately $60 \%$ of all cysts found in the mandible, which accounts for $52 \%$ to $68 \%$ of all cysts affecting the oral cavity ${ }^{31}$.

The treatment for this pathology can be diverse, ranging from conservative treatments through endodontic treatment without apicoectomy to more ablative procedures ${ }^{32}$. Endodontic treatment with posterior apicectomy and enucleation is a less invasive procedure performed from a small bone shop with access to the lesion; after successful treatment, bone neoformation is possible and the patient can be followed clinically and radiographically with minimal chances of relapse ${ }^{33}$.

\section{Conclusion:-}

It can be concluded from this study that:

The root cyst can reach large proportions when not treated or discovered late, mainly because it is a pathology that does not present painful symptomatology in initial conditions unless it is infected. It is usually discovered by chance, or by routine radiographic examination. Thus, adequate planning, knowledge of surgical techniques, effective treatment or endodontic retreatment are necessary, increasing the chances of success in the treatment chosen.

\section{Conflict Of Interests:-}

The authors declare they do not have any conflict of interests. 


\section{References:-}

1. Peixoto RF, Peixoto DF. Immunological and Etiopathogenic Aspects of Chronic Inflammatory Periapical Lesions. UNOPAR Cient Ciênc Biol Saúde 2012; 14(3):175-82.

2. Mendonça DWR, Conceição HC, Martins VB, Lima KA. Tratamento cirurgico de cisto radicular em maxilla: relato de caso. Arch Health Invest. 2017; 6(8).

3. Neville BW, Damm DD, Allen CM, Bouquot JE. Patologia oral \& maxilofacial. 3. ed., Rio de Janeiro:Guanabara Koogran; 2009.

4. Martins-Filho PRS, Brasileiro BF, Piva MR, Silva LCF, Reinheimer DM, Marzola C. Cisto radicular na maxila relato de caso clínico cirúrgico. Rev ATO. 2009; 4(10):881-9.

5. Dantas RMX, Dultra JA, Borges GL, Dultra FKAA, Neri RFA. Enucleação de cisto radicular maxilar associado à apicectomia: relato de caso. Rev. Cir. Traumatol. Buco-Maxilo-Fac, 2014; 14(3);21-26.

6. Vasconcelos RG, Queiroz LMG, Junior LCA, Germano AR, Vasconcelos MG. Abordagem terapêutica em cisto radicular de grandes proporções - relato de caso. R bras ci Saúde. 2012; 16(3):467-474.

7. Feix LM, Boijink D, Ferreira R, Wagner MH, Barletta FB. Microscópio operatório na endodontia: Magnificação visual e luminosidade. Rev Sul-Bras Odontol. 2010; 7(3):340-8.

8. Neto MM, Danesi CC, Unfer DT. Contribuição ao estudo do cisto radicular revisão da literatura. Saúde. 2004; 30 (1-2):90-99.

9. D’Adazzio PSS, Assis NMSP, Campos CN, Bastos TR, Lopes RM. Uso da tomografia Cone Beam no auxilio ao diagnóstico e planejamento de cirurgia periapical: Relato de caso clínico. Odontol. Clín.-Cient. 2010; 9(4)377-380.

10. Garib DG, Junior RR, Raymundo MV, Raymundo DV, Ferreira SN. Tomografia computadorizada de feixe cônico (cone beam): entendendo este novo método de diagnóstico por imagem com promissora aplicabilidade na Ortodontia. R Dental Press Ortodon Ortop Facial. 2007; 12( 2):139-156.

11. Carvalho MGP, Perez WB, Matter SB, Blaya DS, Anhald AC. Apicetomia seguida de obturação retrógrada com agregado trióxido mineral (MTA) - relato de caso clínico. Revista de Endodontia Pesquisa e Ensino On Line. 2005; 1(2).

12. Pozzer L, Jaimes M, Neto HDMC, Olate S, Barbosa JRA. Cistos odontogenicos em crianças: Análise da descompressão cirúrgica em dois casos. Rev. Cir. Traumatol. Buco-Maxilo-fac. 2009; 9(2):17-22.

13. Alves IFS, Mesquita JP, Queiroz NB, Queiroz GL, Cabral ARA. Enucleação de cisto radicularmaxilar de grande extensão: Relato de caso. Jornada Odontológica dos Acadêmicos da Católica - JOAC. 2016; 2(2).

14. Arieta LC, Silva MAA, Rockenbach MIB, Veek EB. Extensões dos seios maxilares detectadas em radiografias periapicais. Revista Odonto Ciência. 2005; 20(47).

15. Silva MP, Eidt JMS, Danieletto CF, Endo MS, Pavan NNO, Filho LI. Abordagem cirúrgica associada a retratamento endodôntico para tratamento de cisto radicular. Arch Health Invest. 2016; 5(1): 17-369.

16. Cavalli D, Modolo F, Rivero ERC. Avaliação do metabolismo epitelial em cistos radiculares pela técnica de AgNORS. Rev Odontol UNESP. 2014; 43(2): 77-81.

17. Azambuja TWF, Bercini F, Alano F. Cirurgia Parendodontica: Revisão de literatura e apresentação de casos clínico-cirurgicos. Rev Odontol UNESP. 2014; 43(2): 77-81.

18. Secco M, Burzlaff JB. Obturação simultânea do canal radicular após enucleação de cisto apical: Uma revisão multidisciplinar. Trabalho de Conclusão de Curso, Faculdade de Odontologia - Uiversidade Federal do Rio Grande do Sul, Porto Alegre; 2011.

19. Politano GT et al. Cisti Radicular: Relato de caso clinico. ConScientiae Saúde, 2009;8(1):129-132.

20. Silveira EJD, Piva MR, Galvão HC, Souza LB, Freitas RA. Participação das metaloproteinases da matriz na etiopatogenia dos cistos odontogênicos. Bras Patol Med Lab. 2007; 43(3):203-209.

21. Oliveira DHIP et al. Cisto residual com grande dimensão: Relato de caso e revisão da literatura. Rev. Cir. Traumatol. Buco-Maxilo-Fac. 2011; 11(2):21-26.

22. Pereira JS, Milagres RM, Andrade BAB, Messora MR, Kawata LT. Cisto periapical de grande extensão: Relato de caso. Rev. Cir. Traumatol. Buco-Maxilo-Fac. 2012; 12(2):37-42.

23. Oliveira MDC, Souza LB, Pinto LP, Freitas RA. Estudo imuno-histoquímico de componentes da membrana basal em cistos odontogênicos. Pesqui Odontol Bras 2002;16(2):157-162.

24. Tijoe KC, Imada TSN, Pardo MP, Consolaro A, Gonçalves ES. Cisto radicular inflamatório extenso envolvendo seio maxilar. Rev Assoc Paul Cir Dent 2015;69(4):383-6.

25. Igreja FF, Penna I, Camisasca DR, Barros LAP, Pereira TCR. Marsupialização como tratamento inicial de cisto do ducto nasopalatino. Rev. Cir. TraumatolBuco-Maxilo-Fac. 2005; 5(2):41-48.

26. Utumi ER, Pedron IG, Silva LPN, Machado GG, Rocha AC. Different manifestations of calcifying cystic odontogenic tumor. einstein. 2012;10(3):366-70. 
27. Colombo CED et al. Levantamento epidemiológico dos casos clínicos diagnosticados no serviço de patologia do curso de odontologia da FCS - UNIVAP. IX Encontro Latino Americano de Iniciação Científica e V Encontro Latino Americano de Pós-Graduação - Universidade do Vale do Paraíba, Faculdade de Ciências da Saúde (FCS) - Universidade do Vale do Paraíba (UNIVAP), pag. 1561-1564.

28. Pinto SIT. Uma abordagem sobre infecções endodônticas. Universidade Fernando Pessoa, Faculdade de Ciências da Saúde, Porto 2016.

29. Santos LCS, Ramos EAG, Meira TM, Figueiredo CRLV, Santos JN. Etiopatogenia do cisto radicular: parte I. R. Ci. méd. biol. 2006; 5(1):69-74.

30. Signoretti FCG, Jacinto RC, Gomes BPFA. Avaliação microbiológica de lesões periapicais crônicas associadas ao insucesso do retratamento endodôntico. Universidade Estadual de Campinas - Faculdade de Odontologia de Piracicaba, Piracicaba, 2013.

31. Jardim TH, Swarowsky P, Butzke KW. A aplicação da tomografia computadorizada Cone Beam no diagnostico de cisto residual: Estudo de caso. Universidade de Santa Cruz do Sul; Santa Cruz do Sul, 2015.

32. Moura PM, Lima LV, Faria MDB, Gutfilen B. Expansão rápida da maxila - avaliação de dois métodos de reconstrução 3D por meio de um modelo laboratorial. R Dental Press Ortodon Ortop Facial. 2009; 14(1):90-93.

33. Junqueira RB et al. Tomografia computadorizada de feixe cônico como instrumento complementar de diagnóstico e planejamento cirúrgico de cisto radicular: Relato de caso clínico. Rev Odontol UNESP. 2011; 40(6): 338-343 